\title{
PENGARUH KINERJA KEUANGAN DAN INFLASI TERHADAP RETURN ON ASSET PADA BANK UMUM SYARIAH DI INDONESIA
}

\author{
Idris Saleh \\ Institut Agama Islam Negeri (IAIN) Padangsidimpuan, Indonesia \\ idrissaleh@iain-padangsidimpuan.ac.id \\ https://doi.org/10.46367/jps.v2i2.369
}

Received: Jul 05, 2021 Revised: Aug 20, 2021 Accepted: Sep 09, 2021 Published: Oct 14, 2021

\begin{abstract}
This research aims to show the effect of capital adequacy ratio $(C A R)$, financing to deposit ratio $(F D R)$, non-performing financing (NPF), operating expenses on operating income (BOPO), and inflation partially and simultaneously on return on assets (ROA) at Sharia Commercial Bank in Indonesia. This type of research is a quantitative research using secondary data based on panel data. The research population consisted of 11 Islamic Commercial Banks in Indonesia using the purposive sampling technique so that 220 samples were obtained. The data analysis technique used is panel data regression method, classical assumption test, coefficient of determination, $t$-test, and f-test. The results show that CAR has a positive and significant effect on ROA, FDR has a negative and insignificant effect on ROA, NPF, and inflation has a positive effect and is not significant on ROA. At the same time, BOPO has a negative and significant effect on ROA. Simultaneously all independent variables have a significant effect on ROA.
\end{abstract}

Keywords: CAR, FDR, NPF, BOPO, Inflation, ROA, Sharia Commercial Bank.

\begin{abstract}
ABSTRAK
Penelitian ini bertujuan untuk menunjukkan pengaruh capital adequacy ratio $(C A R)$, financing to deposit ratio $(F D R)$, non-performing financing $(N P F)$, beban operasional pendapatan operasional (BOPO) dan inflasi secara parsial dan simultan terhadap return on asset (ROA) pada Bank Umum Syariah di Indonesia. Jenis penelitian ini adalah penelitian kuantitatif menggunakan data sekunder berdasarkan pada data panel. Populasi penelitian terdiri dari 11 Bank Umum Syariah di Indonesia dengan menggunakan teknik purposive sampling sehingga didapat 220 data sampel. Teknik analisis data yang digunakan adalah metode regresi data panel, uji asumsi klasik, koefisien determinasi, uji t dan uji f. Hasil penelitian menunjukkan bahwa $C A R$ berpengaruh positif dan signifikan terhadap $R O A, F D R$ berpengaruh negatif dan tidak signifikan terhadap $R O A, N P F$ dan inflasi berpengaruh positif dan tidak signifikan terhadap $R O A$. Sedangkan BOPO berpengaruh negatif dan signifikan terhadap $R O A$. Secara simultan semua variabel bebas memiliki pengaruh yang signifikan terhadap $R O A$.
\end{abstract}

Kata Kunci: $C A R, F D R, N P F$, BOPO, Inflasi, ROA, Bank Umum Syariah. 


\section{PENDAHULUAN}

Perkembangan bank syariah yang dikategorikan ke dalam Bank Umum Syariah (BUS) dinilai cukup pesat dalam melebarkan sayap. Pada tahun 2000 baru beroperasi sebanyak dua BUS. Tahun 2010 menjadi 11 BUS dengan jumlah kantor sebanyak 1215. Tahun 2015 berkembang menjadi 12 BUS dengan 1990 kantor dan di tahun 2016 bertambah 1 BUS menjadi 13 BUS dan 1869 kantor, dimana BUS tersebut merupakan hasil spin off Unit Usaha Syariah (UUS). Pertumbuhan BUS mengalami peningkatan hampir disetiap tahunnya, begitu pula dengan aset yang dimiliki BUS, juga mengalami peningkatan.

Keberhasilan suatu bank bukan terletak pada jumlah modal yang dimilikinya, tetapi lebih didasarkan kepada bagaimana bank tersebut mempergunakan modal itu untuk menarik sebanyak mungkin dana atau simpanan masyarakat yang kemudian disalurkannya kembali kepada masyarakat yang membutuhkannya sehingga membentuk pendapatan bagi hasil bank tersebut. Untuk itu, sebuah bank diwajibkan melaporkan data keuangan dan rasio keuangan dari bank tersebut, dengan tujuan untuk melaporkan kinerja bank secara transparan seperti $C A R, F D R, N P F$, dan BOPO. Begitu juga dengan penambahan variabel inflasi, diharapkan mampu mengukur tingkat profitabilitas (ROA) dilihat dari segi eksternal bank. Bukan faktor internal bank saja, yang mampu mempengaruhi kinerja bank. Faktor eksternal juga sangat perlu diperhatikan karena inflasi yang tidak stabil akan berdampak terhadap kinerja bank.

Penelitian mengenai $R O A$ sudah banyak diteliti oleh peneliti sebelumnya dengan aspek-aspek yang beragam. Penelitian yang membahas mengenai $C A R$ terhadap ROA sudah pernah dilakukan oleh Sabir M. et al. (2012); Lestari and Widyawati (2014); Christiano et al. (2015); Nugraheni (2015); Pranata (2015); Mahmudah and Harjanti (2016); Hakiim and Rafsanjani (2016) dengan hasil yang beragam. Kemudian penelitian mengenai $F D R$ terhadap $R O A$ juga sudah pernah diteliti oleh Sabir M. et al. (2012); Lestari and Widyawati (2014); Christiano et al. (2015); Indarwati and Anan (2015); Pranata (2015); Nugraheni (2015); Hakiim and Rafsanjani (2016); Lemiyana and Litriani (2016); Mahmudah and Harjanti (2016); Sari et al. (2021) dengan hasil beragam pula. Selanjutnya penelitian mengenai $N P F$ terhadap ROA juga sudah diteliti oleh Sabir M. et al. (2012); Lestari and Widyawati (2014); Christiano et al. (2015); Nugraheni (2015); Lemiyana and Litriani (2016); Mahmudah and Harjanti (2016); Sari et al. (2021) dengan hasil yang juga beragam.

Penelitian mengenai BOPO terhadap ROA sudah pernah dilakukan oleh (Sabir M. et al. (2012); Lestari and Widyawati (2014); Christiano et al. (2015); Indarwati and Anan (2015); Nugraheni (2015); Hakiim and Rafsanjani 2016; Lemiyana and Litriani (2016) dengan hasil yang beragam. Selanjutnya penelitian mengenai inflasi terhadap ROA sudah pernah dilakukan oleh Sahara (2013); Wibowo and Syaichu (2013); Alim (2014) dengan hasil yang beragam pula. Akan tetapi dari semua penelitian tersebut belum ada yang membahas pengaruh $C A R$, $F D R, N P F$, BOPO dan inflasi terhadap ROA secara simultan. Selain itu yang membedakan dengan penelitian sebelumnya yaitu mengenai waktu dan sampel yang digunakan, sehingga hal tersebut dapat dijadikan gap penelitian. Oleh sebab itu penelitian ini bertujuan untuk menunjukkan pengaruh $C A R, F D R, N P F$, BOPO dan inflasi secara parsial dan simultan terhadap ROA pada BUS di Indonesia. 


\section{TELAAH LITERATUR}

\section{Return On Assets (ROA)}

$R O A$ adalah rasio yang menunjukkan perbandingan antara laba (sebelum pajak) dengan total aset bank, rasio ini menunjukkan tingkat efisiensi pengelolaan aset yang dilakukan oleh bank yang bersangkutan (Pandia 2012). Semakin besar $R O A$ suatu bank, maka semakin besar tingkat keuntungan bank dan semakin baik pula posisi bank dari segi penggunaan aset. Semakin kecil rasio ini mengindikasikan kurangnya kemampuan manajemen bank dalam hal mengelola aktiva untuk meningkatkan pendapatan dan menekan biaya (Rivai and Arifin 2013). Rasio ini digunakan untuk mengukur kemampuan manajemen bank dalam memperoleh keuntungan (laba) secara keseluruhan. Adapun rasio ini dapat dirumuskan dengan:

$$
R O A=(\text { Laba Bersih }) /(\text { Total Aset }) \times 100 \%
$$

\section{Capital Adequacy Ratio (CAR)}

$C A R$ adalah rasio yang memperlihatkan seberapa jauh seluruh aktiva yang mengandung risiko ikut dibiayai dari dana modal sendiri bank di samping memperoleh dana-dana dari sumber di luar bank (Dendawijaya 2005). Dengan kata lain, $C A R$ adalah rasio kinerja bank untuk mengukur kecukupan modal yang dimiliki bank untuk menunjang aktiva yang mengandung atau menghasilkan risiko, misalnya kredit yang diberikan (Fahmi 2015). Penilaian permodalan suatu bank dapat ditentukan dengan menggunakan rumus:

$$
C A R=\frac{\text { Modal }}{\text { Aktiva Tertimbang Menurut Risiko (ATMR) }} \times 100 \%
$$

\section{Financing to Deposit Ratio (FDR)}

$F D R$ adalah rasio antara seluruh jumlah kredit/pembiayaan yang diberikan bank dengan dana yang diterima oleh bank (Dendawijaya 2005). FDR tersebut menyatakan seberapa jauh kemampuan bank dalam membayar kembali penarikan dana yang dilakukan deposan dengan mengandalkan kredit/pembiayaan yang diberikan sebagai sumber likuiditasnya (Hutagalung 2020). Dengan demikian, $F D R$ ini menyatakan seberapa jauh kemampuan dalam membayar kembali penarikan dana yang dilakukan masyarakat dengan mengandalkan pembiayaan yang diberikan sebagai sumber likuiditasnya. Semakin besar pembiayaan maka pendapatan yang diperoleh juga akan naik, karena pendapatan naik secara otomatis laba juga akan mengalami kenaikan. Artinya, seberapa jauh pemberian pembiayaan kepada customer pembiayaan dapat mengimbangi kewajiban untuk dapat segera memenuhi permintaan nasabah yang ingin menarik kembali dananya yang telah digunakan untuk memberikan pembiayaan. Semakin tinggi rasio tersebut, memberikan indikasi rendahnya kemampuan likuiditas bank yang bersangkutan (Lemiyana and Litriani 2016). Hal ini disebabkan jumlah dana yang diperlukan untuk membiayai pembiayaan menjadi semakin besar. Adapun rumus FDR sebagai berikut:

$$
F D R=\frac{\text { Jumlah Pembiayaan }}{\text { Total Dana Pihak Ketiga }} \times 100 \%
$$




\section{Non Performing Financing (NPF)}

Menurut Ismail (2010), NPF atau kredit bermasalah/pembiayaan bermasalah merupakan kredit/pembiayaan yang telah disalurkan oleh bank, dan nasabah tidak dapat melakukan pembayaran atau melakukan angsuran sesuai dengan perjanjian yang telah ditandatangani oleh bank dan nasabah. Sedangkan menurut Taswan (2010), NPF yaitu perbandingan antara kredit/pembiayaan bermasalah terhadap total kredit/pembiayaan. Rasio ini mengindikasikan bahwa semakin tinggi rasio NPF menunjukkan semakin buruk kualitas kreditnya/ pembiayaannya. Sedangkan menurut Kuncoro and Suhardjono (2012), kredit bermasalah/pembiayaan bermasalah adalah suatu keadaan di mana nasabah sudah tidak sanggup membayar sebagian atau seluruh kewajibannya kepada bank seperti yang telah diperjanjikannya. Semakin tinggi rasio ini, menunjukkan kualitas pembiayaan bank syariah semakin buruk. Tingkat kesehatan NPF ikut mempengaruhi pencapaian laba bank. Pengelolaan pembiayaan sangat diperlukan oleh bank, mengingat fungsi pembiayaan sebagai penyumbang pendapatan terbesar bagi bank syariah (Nugraheni 2015). Secara matematis $N P F$ dirumuskan sebagai berikut:

$$
N P F=\frac{\text { Jumlah Pembiayaan Bermasalah }}{\text { Total Pembiayaan yang disalurkan }} \times 100 \%
$$

Semakin tinggi $N P F$, maka profitabilitas akan semakin rendah dan sebaliknya, jika $N P F$ semakin rendah, maka profitabilitas akan semakin tinggi. Jika kredit bermasalah sangat besar dan cadangan yang dibentuk juga besar, berakibat modal bank kemungkinan menjadi negatif sehingga laba yang diperoleh menjadi terganggu. Pembiayaan bermasalah dalam jumlah besar akan menurunkan tingkat operasi bank tersebut. Apabila penurunan pembiayaan dan profitabilitas sudah sangat parah sehingga mempengaruhi profitabilitas, likuiditas dan solvabilitas suatu bank, maka kepercayaan para penitip dana terhadap bank akan hilang (Fazriani and Mais 2019).

\section{Beban Operasional Pendapatan Operasional (BOPO)}

BOPO adalah rasio perbandingan antara biaya atau beban operasional dengan pendapatan operasional. Rasio yang sering disebut rasio efisiensi ini digunakan untuk mengukur kemampuan manajemen bank dalam mengendalikan biaya atau beban operasional terhadap pendapatan operasional (Dendawijaya 2005). Semakin kecil rasio ini berarti semakin efisien biaya operasional yang dikeluarkan bank yang bersangkutan sehingga kemungkinan suatu bank dalam kondisi bermasalah semakin kecil. Semakin tinggi rasio ini menunjukkan semakin tidak efisien biaya operasional bank (Hakiim and Rafsanjani 2016). Adapun rumus rasio ini adalah:

$$
\text { BOPO }=\frac{\text { Beban Operasional }}{\text { Pendapatan Operasional }} \times 100 \%
$$

\section{Inflasi}

Inflasi adalah kenaikan harga barang-barang yang bersifat umum dan terus menerus. Dengan melihat indeks harga konsumen (IHK). Apabila laju inflasi tinggi serta tidak dapat dikendalikan, maka upaya perbankan dalam 
menghimpunan dana masyarakat akan terganggu sehingga penyaluran pembiayaan menjadi tersendat dan menurun. Jadi inflasi yang meningkat akan menyebabkan nasabah akan menarik dana dari bank untuk memenuhi kebutuhan akibat meningkatnya harga barang dan jasa serta nilai mata uang rupiah yang menurun untuk memenuhi kebutuhan mereka, sehingga keinginan masyarakat untuk menyimpan dananya pada bank akan menurun. Hal ini dapat mempengaruhi pembiayaan bank, sehingga penyaluran pembiayaan akan menurun dan menjadikan pendapatan sekaligus keuntungan bank akan menurun. Semakin tinggi tingkat inflasi maka semakin besar selisih harga barang setelah adanya inflasi yang mengakibatkan harga barang menjadi lebih mahal. Inflasi termasuk salah satu indikator ekonomi makro yang berpengaruh terhadap kinerja keuangan perusahaan. Inflasi diukur dengan tingkat inflasi, yaitu tingkat perubahan dari tingkat harga secara umum. Persamaannya adalah sebagai berikut (Karim 2006):

\section{Tingkat Inflasi $=$ Tingkat Harga $\mathrm{t}_{\mathrm{t}}-$ Tingkat Harga $_{\mathrm{t}-1} \times 100$ \\ Tingkat Harga $t-1$}

\section{Pengembangan Hipotesis}

Penelitian yang dilakukan oleh Christiano et al. (2015); Nugraheni (2015); Pranata (2015); Mahmudah and Harjanti (2016) menunjukkan hasil bahwa CAR berpengaruh dan signifikan terhadap ROA. Berdasarkan hasil penelitian tersebut maka dapat dirumuskan hipotesis pertama sebagai berikut:

$\mathrm{H}_{1}$ : $C A R$ berpengaruh signifikan terhadap ROA pada BUS.

Penelitian yang dilakukan oleh Sabir M. et al. (2012); Christiano et al. (2015); Indarwati and Anan (2015); Pranata (2015); Sari et al. (2021) menunjukkan hasil bahwa $F D R$ berpengaruh dan signifikan terhadap ROA. Berdasarkan hasil penelitian tersebut dapat dirumuskan hipotesis kedua sebagai berikut:

$\mathrm{H}_{2}$ : FDR berpengaruh signifikan terhadap $R O A$ pada BUS.

Penelitian yang dilakukan oleh Christiano et al. (2015); Nugraheni (2015); Sari et al. (2021) menunjukkan hasil bahwa NPF memiliki pengaruh dan signifikan terhadap $R O A$. Berdasarkan hasil penelitian tersebut dapat dirumuskan hipotesis ketiga sebagai berikut:

$\mathrm{H}_{3}$ : NPF berpengaruh signifikan terhadap ROA pada BUS.

Penelitian yang dilakukan oleh Christiano et al. (2015); Lestari and Widyawati (2014); Indarwati and Anan (2015); Nugraheni (2015); Hakiim and Rafsanjani (2016); Lemiyana and Litriani (2016) menunjukkan hasil bahwa BOPO berpengaruh dan signifikan terhadap ROA. Berdasarkan hasil penelitian tersebut dapat dirumuskan hipotesis keempat sebagai berikut:

$\mathrm{H}_{4}$ : BOPO berpengaruh signifikan terhadap $R O A$ pada BUS.

Penelitian yang dilakukan oleh Sahara (2013); (Alim 2014) menunjukkan hasil bahwa inflasi memiliki pengaruh terhadap ROA. Berdasarkan hasil penelitian tersebut dapat dirumuskan hipotesis kelima dan dari semua variabel penelitian dirumuskan hipotesis keenam, sebagai berikut:

$\mathrm{H}_{5}$ : Inflasi berpengaruh signifikan terhadap $R O A$ pada BUS

$\mathrm{H}_{6}$ : $C A R, F D R, N P F, B O P O$ dan inflasi berpengaruh signifikan terhadap $R O A$ pada BUS. 


\section{METODE PENELITIAN}

Jenis penelitian ini adalah penelitian kuantitatif. Data kuantitatif adalah data yang diukur dalam suatu skala numerik (angka). Variabel yang digunakan adalah variabel bebas (independen) meliputi $C A R, F D R, N P F, B O P O$ dan Inflasi serta variabel terikat (dependen) yang meliputi tingkat $R O A$. Sumber data yang digunakan adalah data sekunder yang diperoleh dari website OJK, yaitu https://www.ojk.go.id. Adapun populasi dalam penelitian ini adalah seluruh laporan keuangan Bank Umum Syariah yang di publikasikan dan terdaftar di Otoritas Jasa Keuangan (OJK) dan data tingkat inflasi berasal dari Bank Indonesia (BI). Teknik pengambilan sampel menggunakan purposive sampling dengan kriteria: (a) menerbitkan laporan keuangan triwulan BUS pada tahun 2012-2016, (b) Besaran sampel penelitian yang diambil dari penelitian ini adalah laporan keuangan triwulan dari 11 Bank Umum Syariah di Indonesia pada tahun 20122016 yaitu Bank Muamalat Indonesia, Bank Syariah Mandiri, BNI Syariah, BRI Syariah, Bank Victoria Syariah, Bank Jabar Banten Syariah, Bank Mega Syariah, Bank Panin Syariah, Bank Syariah Bukopin, BCA Syariah dan Maybank Syariah Indonesia. BTPN Syariah tidak dimasukkan dalam sampel karena baru beroperasi pada Juli 2014 dan Bank Aceh Syariah juga tidak masuk karena baru beroperasi pada tahun 2016. Sehingga jumlah sampel yang digunakan dalam penelitian ini berjumlah 220 data. Teknik pengumpulan data menggunakan teknik pustaka dan dokumentasi berupa buku, paper jurnal terkait dan laporan keuangan bulanan BUS dari website OJK. Teknik analisa data menggunakan uji asumsi klasik dan analisis regresi linier berganda data panel dengan menggunakan alat bantu aplikasi Eviews.

\section{HASIL DAN PEMBAHASAN PENELITIAN}

\section{Uji Multikolinearitas}

Uji multikoliniearitas bertujuan unutk menguji apakah dalam suatu model regresi ditemukan adanya korelasi antarindependen atau tidak. Dari hasil uji multikolinearitas pada Tabel 1, diperoleh hasil bahwa tidak ada nilai koefisien korelasi yang lebih dari 0,85 . Hal ini membuktikan bahwa tidak terjadi masalah multikolinearitas antar variabel independen dalam model regresi.

Tabel 1. Uji Multikolinearitas

\begin{tabular}{crrrrr}
\hline Variabel & $\boldsymbol{C A R}$ & $\boldsymbol{F D R}$ & $\boldsymbol{N P F}$ & BOPO & \multicolumn{1}{c}{ Inflasi } \\
\hline $\boldsymbol{C A R}$ & 1,000000 & 0,708860 & $-0,321257$ & $-0,061560$ & $-0,074632$ \\
$\boldsymbol{F D R}$ & 0,708860 & 1,000000 & $-0,131059$ & $-0,043280$ & 0,035076 \\
$\boldsymbol{N P F}$ & $-0,321257$ & $-0,131059$ & 1,000000 & 0,438294 & $-0,058872$ \\
BOPO & $-0,061560$ & $-0,043280$ & 0,438294 & 1,000000 & $-0,148669$ \\
Inflasi & $-0,074632$ & 0,035076 & $-0,058872$ & $-0,148669$ & 1,000000 \\
\hline Sumber: data sekunder (diolah)
\end{tabular}

\section{Uji Heteroskedastisitas}

Heteroskedastisitas dapat diartikan sebagai ketidaksamaan variasi variabel pada semua pengamatan, dan kesalahan yang terjadi memperlihatkan hubungan yang sistematis sesuai dengan besarnya satu atau lebih variabel bebas sehingga kesalahan tersebut tidak random (acak). Berdasarkan hasil uji heteroskedastisitas 
pada Tabel 2 terlihat bahwa tidak adanya hubungan yang signifikan antara seluruh variabel independen terhadap nilai absolut residual. Hal ini dibuktikan dengan nilai $P$-value seluruh variabel independen $>\alpha(0,05)$. Sehingga dapat dikatakan bahwa tidak terjadi masalah heteroskedastisitas dalam model regresi.

Tabel 2. Uji Heteroskedastisitas

\begin{tabular}{ccccc}
\hline Variable & Coefficient & Std. Error & t-Statistic & Prob. \\
\hline C & $-0,188528$ & 0,590314 & $-0,319369$ & 0,7498 \\
CAR & 0,014900 & 0,010014 & 1,487930 & 0,1383 \\
$\boldsymbol{F D R}$ & $-0,004095$ & 0,002490 & $-1,644613$ & 0,1016 \\
$\boldsymbol{N P F}$ & 0,005769 & 0,038023 & 0,151721 & 0,8796 \\
BOPO & 0,010336 & 0,003107 & 3,326543 & 0,0710 \\
Inflasi & $-0,016947$ & 0,026545 & $-0,638409$ & 0,5239 \\
\hline Sumber: data sekunder(diolah) & & &
\end{tabular}

\section{Uji Autokorelasi}

Uji autokorelasi digunakan untuk mengetahui ada tidaknya korelasi serial pada variabel pengganggu. Tidak adanya gejala autokorelasi dapat dibuktikan dengan uji Durbin-Watson (DW), dengan ketentuan nilai DW lebih besar dari -2 dan lebih kecil dari +2 . Berdasarkan hasil uji autokorelasi pada Tabel 3 terlihat bahwa nilai Durbin Watson sebesar 1,267852, sehingga dapat dikatakan bahwa tidak terjadi masalah autokorelasi. Hal ini dibuktikan dengan nilai Durbin-Watson lebih besar dari -2 dan lebih kecil dari $+2(-2<1,267852<+2)$.

\section{Analisis Regresi Data Panel}

Setelah melakukan serangkaian pengujian regresi data panel, penelitian ini menggunakan estimasi Fixed Effect Model. Berdasarkan Tabel 3, model regresi yang terbentuk adalah $R O A=11,3591541777+0,0423461428399$ CAR $0,00355156112862 F D R+0,0103281020736 N P F-0,123596738694 \mathrm{BOPO}+$ 0,0183427337065 inflasi. Untuk lebih sederhana, maka dilakukan pembulatan, sehingga persamaan menjadi $R O A=11,359+0,042 C A R-0,004 F D R+0,010$ $N P F-0,124 \mathrm{BOPO}+0,018$ inflasi.

Persamaan hasil regresi dapat dijabarkan, bahwa nilai konstanta sebesar 11,359 menunjukkan bahwa jika $C A R, F D R, N P F$, BOPO dan inflasi nilainya 0 , maka nilai rata-rata ROA BUS sebesar 11,359. Koefisien $C A R$ sebesar 0,042 menunjukkan bahwa jika CAR meningkat $1 \%$, maka ROA BUS akan mengalami peningkatan sebesar 0,042 dengan asumsi nilai variabel independen lainnya konstan. Koefisien FDR sebesar -0,004 menunjukkan bahwa jika FDR meningkat $1 \%$, maka ROA BUS akan mengalami penurunan sebesar $-0,004$ dengan asumsi nilai variabel independen lainnya konstan. Koefisien $N P F$ sebesar 0,010 menunjukkan bahwa jika $N P F$ meningkat $1 \%$, maka ROA BUS akan mengalami peningkatan sebesar 0,010 dengan asumsi nilai variabel independen lainnya konstan. Koefisien BOPO sebesar $-0,124$ menunjukkan bahwa jika BOPO meningkat $1 \%$, maka ROA BUS akan mengalami penurunan sebesar -0,124 dengan asumsi nilai variabel independen lainnya konstan. Koefisien inflasi sebesar 0,018 menunjukkan bahwa jika inflasi meningkat 1\%, maka ROA BUS akan mengalami peningkatan sebesar 0,018 dengan asumsi nilai variabel independen lainnya konstan. 
Tabel 3. Hasil Regresi Data Panel dengan Estimasi Fixed Effect Model

\begin{tabular}{ccccc}
\hline \multicolumn{1}{c}{ Variable } & Coefficient & Std. Error & t-Statistic & Prob. \\
\hline C & 11,35915 & 0,914009 & 12,42783 & 0,0000 \\
CAR & 0,042346 & 0,015505 & 2,731153 & 0,0069 \\
FDR & $-0,003552$ & 0,003856 & $-0,921141$ & 0,3581 \\
NPF & 0,010328 & 0,058873 & 0,175431 & 0,8609 \\
BOPO & $-0,123597$ & 0,004811 & $-25,69197$ & 0,0000 \\
Inflasi & 0,018343 & 0,041101 & 0,446284 & 0,6559 \\
\hline R-squared & 0,881344 & Mean dependent var & 0,578727 \\
Adjusted $R$-squared & 0,872619 & S.D. dependent var & 2,928820 \\
S.E. of regression & 1,045310 & Akaike info criterion & 2,996450 \\
Sum squared resid & 222,9052 & Schwarz criterion & 3,243260 \\
Log likelihood & $-313,6096$ & Hannan-Quinn criter. & 3,096119 \\
F-statistic & 101,0168 & Durbin-Watson stat & 1,267852 \\
Prob(F-statistic) & 0,000000 & & \\
\hline Sumber: data sek & & &
\end{tabular}

Sumber: data sekunder (diolah)

\section{Uji Hipotesis}

Kriteria pengujian hipotesis pada uji $\mathrm{t}$ (parsial) berdasarkan nilai $\mathrm{t}_{\text {hitung, }}$ jika $\mathrm{t}_{\text {hitung }}>\mathrm{t}_{\mathrm{tabel}}$ dan probability $<$ level of signifikan $(0,05)$, maka terdapat pengaruh yang signifikan dari variabel bebas terhadap variabel terikat. Sebaliknya, jika $\mathrm{t}_{\text {hitung }}\left\langle\mathrm{t}_{\text {tabel }}\right.$ atau $-\mathrm{t}_{\text {hitung }}>-\mathrm{t}_{\text {tabel }}$ dan probability $>$ level of signifikan $(0,05)$, maka tidak ada pengaruh dan tidak signifikan dari variabel bebas terhadap variabel terikat. Kriteria pengujian hipotesis pada uji $\mathrm{F}$ (simultan) berdasarkan nilai $\mathrm{F}_{\text {hitung, }}$ jika $\mathrm{F}_{\text {hitung }}>\mathrm{F}_{\text {tabel }}$ dan probability < level of signifikan $(0,05)$, maka terdapat pengaruh yang signifikan dari variabel bebas terhadap variabel terikat. Sebaliknya, jika $\mathrm{F}_{\text {hitung }}\left\langle\mathrm{F}_{\text {tabel }}\right.$ atau $\left.-\mathrm{F}_{\text {hitung }}\right\rangle-\mathrm{F}_{\text {tabel }}$ dan probability $>$ level of signifikan $(0,05)$, maka tidak ada pengaruh dan tidak signifikan dari variabel bebas terhadap variabel terikat.

Berdasarkan tabel 3 dapat dilihat bahwa untuk variabel $C A R$, $\mathrm{t}_{\text {hitung }}$ $(2,73115)>t_{\text {tabel }}(1,65195)$ dan probabilitas $(0,0069)<0,05$, maka terdapat pengaruh yang signifikan antara $C A R$ terhadap $R O A\left(\mathrm{H}_{1}\right.$ diterima). Variabel $F D R$, $\mathrm{t}_{\text {hitung }}(-0,921141)<\mathrm{t}_{\text {tabel }}(-1,65195)$ dan probabilitas $(0,3581)>0,05$, maka tidak terdapat pengaruh dan tidak signifikan antara $F D R$ terhadap $R O A\left(\mathrm{H}_{2}\right.$ ditolak). Variabel $N P F, \mathrm{t}_{\text {hitung }}(0,175431)<\mathrm{t}_{\text {tabel }}(1,65195)$ dan probabilitas $(0,8609)>0,05$, maka tidak terdapat pengaruh dan tidak signifikan antara $N P F$ terhadap $R O A\left(\mathrm{H}_{3}\right.$ ditolak). Variabel BOPO, $\mathrm{t}_{\text {hitung }}(-25.69197)<\mathrm{t}_{\text {tabel }}(-1,65195)$ dan probabilitas $(0,00)<0,05$, maka terdapat pengaruh dan signifikan antara BOPO terhadap ROA $\left(\mathrm{H}_{4}\right.$ diterima $)$. Variabel Inflasi, $\mathrm{t}_{\text {hitung }}(0.446284)<\mathrm{t}_{\text {tabel }}(1,65195)$ dan probabilitas $(0,6559)>0,05$, maka tidak terdapat pengaruh dan tidak signifikan antara Inflasi terhadap $R O A$ ( $\mathrm{H}_{5}$ ditolak). Sedangkan variabel $C A R, F D R, N P F, \mathrm{BOPO}$ dan inflasi secara simultan, $F_{\text {hitung }}(101,0168)>F_{\text {tabel }}(2,26)$ dan probabilitas $(0,00)<$ 0,05 , maka terdapat pengaruh dan signifikan antara $C A R, F D R, N P F$, BOPO dan inflasi terhadap $R O A$ ( $\mathrm{H}_{6}$ diterima).

\section{Koefisien Determinasi}

Pada tabel 3 diketahui bahwa besarnya Adjusted $R$ Square adalah 0,8727 $(87,27 \%)$. Hal ini berarti bahwa besar pengaruh $C A R, F D R, N P F$, BOPO dan 
inflasi terhadap ROA secara simultan adalah sebesar $87,27 \%$. Sedangkan sisanya $12,73 \%(100 \%-87,27 \%)$ dijelaskan oleh variabel-variabel lain diluar model penelitian ini.

\section{Pengaruh CAR terhadap ROA}

Hasil hipotesis $\mathrm{H}_{1}$ diterima, artinya terdapat pengaruh yang signifikan antara $C A R$ terhadap $R O A$ pada BUS. Hasil ini menunjukkan bahwa semakin besar $C A R$ maka $R O A$ yang diperoleh bank akan semakin besar, karena semakin besar $C A R$ maka semakin tinggi kemampuan permodalan bank dalam menjaga kemungkinan timbulnya risiko kerugian kegiatan usahanya, sehingga kinerja bank juga akan meningkat. Selain itu, semakin tinggi permodalan bank maka bank dapat melakukan ekspansi usahanya dengan lebih aman dan tingginya rasio CAR dapat melindungi nasabah sehingga dapat meningkatkan kepercayaan nasabah terhadap bank. Adanya ekspansi usaha pada akhirnya akan mempengaruhi kinerja keuangan bank yang bersangkutan. Hasil ini sesuai dengan pecking order theory (teori urutan pendanaan) yang menyatakan bahwa perusahaan dengan tingkat profitabilitas yang tinggi dikarenakan perusahaan memiliki modal besar dari sumber dana internal yang berlimpah.

Rata-rata besarnya rasio modal BUS di Indonesia adalah 22,30\%. Menurut peraturan Otoritas Jasa Keuangan nomor 21/PJOK.03/2014 mengenai Kewajiban Penyediaan Modal Minimum Bank Umum Syariah, penyediaan modal minimum ditetapkan paling rendah sebesar $8 \%$. Hal ini menunjukkan bahwa rata-rata BUS di Indonesia menyediakan modal minimum yang tinggi. Semakin tinggi rasio modal, maka semakin rendah biaya eksternal yang dibutuhkan sehingga profitabilitas meningkat.

Bank yang memiliki kecukupan modal, akan memiliki biaya yang lebih rendah ketika mengalami kesulitan keuangan. Hal tersebut merupakan sebuah keunggulan yang kemudian akan diartikan ke dalam profitabilitas yang tinggi. Unutk itu, BUS harus memperhatikan kecukupan modalnya dalam rangka keberlangsungan operasional bank dan menekan biaya operasional untuk meningkatkan profitabilitas.

Selain itu juga terdapat BUS di Indonesia yang mendapat suntikan modal dari induk usaha. Pada tahun 2015, terdapat tiga BUS yang mendapat suntikan modal dari bank induk usaha, yaitu Bank Syariah Mandiri (Rp 500 Milyar), BRI Syariah (Rp 500 Milyar) dan Bank Syariah Bukopin (Rp 350 Milyar). Semakin tinggi jumlah modal yang disuntikkan, maka nasabah akan lebih yakin dan akan lebih menempatkan depositonya di bank. Dengan semakin banyak deposit yang ditempatkan, maka bank memiliki modal yang lebih banyak untuk dikelola dalam rangka menghasilkan profitabilitas yang lebih tinggi. Hasil penelitian ini diperkuat oleh penelitian Christiano et al. (2015); Nugraheni (2015); Pranata (2015); d Mahmudah and Harjanti (2016) yang menyatakan bahwa $C A R$ berpengaruh positif dan signifikan terhadap ROA. Hasil penelitian ini bertolak belakang dengan penelitian yang dilakukan oleh Sabir M. et al. (2012); Hakiim and Rafsanjani (2016) yang menyatakan bahwa $C A R$ tidak berpengaruh terhadap $R O A$.

\section{Pengaruh FDR terhadap ROA}

Hasil hipotesis $\mathrm{H}_{2}$ ditolak, artinya tidak terdapat pengaruh dan tidak signifikan antara FDR terhadap ROA pada BUS. Hal ini disebabkan oleh 
peningkatan dalam pemberian pembiayaan ataupun penarikan dana oleh masyarakat yang berdampak makin rendahnya likuiditas bank. Sehingga berdampak terhadap kepercayaan masyarakat yang pada akhirnya menyebabkan penurunan profitabilitas yang ditandai dengan menurunnya $R O A$.

Dimana rata-rata besarnya rasio FDR BUS di Indonesia adalah 103,09\%. Hal ini mengindikasikan bahwa jumlah pembiayaan yang disalurkan BUS lebih tinggi dari total deposit yang dimiliki. Semakin besar deposit yang disalurkan ke dalam pembiayaan maka semakin tinggi profit yang akan diperoleh. Namun, semakin tinggi pembiayaan yang disalurkan akan meningkatkan biaya pengeluaran untuk persyaratan pembiayaan. Sehingga akan mengurangi profitabilitas yang dimiliki Bank. Oleh karena itu, BUS harus mempertimbangkan aspek kebutuhan biaya yang dikeluarkan ketika menyalurkan pembiayaan agar tidak mengurangi profit yang akan diperoleh.

The liability management theory mengatakan bahwa likuiditas bank dapat dijamin jika bank untuk memenuhi kewajiban keuangannya mencari uang dipasar uang dalam arti luas, pasar uang meliputi pinjaman dari bank lain atau bank sentral dan menitikberatkan pada segi liability (pengelolaan hutang). Dimana maksud teori ini adalah bagaimana bank dapat mengelola pasivanya sedemikian rupa sehingga pasiva tersebut dapat menjadi sumber likuiditas dan dapat meningkatkan profitabilitas bank. Hasil penelitian ini diperkuat oleh penelitian Lemiyana and Litriani (2016); Mahmudah and Harjanti (2016) yang menyatakan bahwa $F D R$ tidak berpengaruh dan terhadap ROA. Hasil penelitian ini bertolak belakang dengan penelitian yang dilakukan oleh Sabir M. et al. (2012); Christiano et al. (2015); Indarwati and Anan (2015); Pranata (2015); Sari et al. (2021) yang menyatakan bahwa FDR berpengaruh positif dan signifikan terhadap ROA.

\section{Pengaruh NPF terhadap ROA}

Hasil hipotesis $\mathrm{H}_{3}$ ditolak, artinya tidak terdapat pengaruh dan tidak signifikan antara $N P F$ terhadap ROA pada BUS. $N P F$ yang tinggi kemungkinan tidak akan memberikan dampak yang dapat menurunkan tingkat $R O A$ pada bank, dikarenakan tidak signifikan dalam mempengaruhi ROA. NPF merupakan rasio yang menunjukkan tingkat pembiayaan yang merupakan salah satu bentuk dari fasilitas pembiayaan yang mengalami permasalahan dalam suatu bank, sehingga apabila rasio NPF mengalami peningkatan dari waktu ke waktu akan mendatangkan masalah serius terhadap kinerja bank.

Permasalahan akan menjadi rumit apabila bank dalam rangka memperoleh penghasilan atau laba yang diharapkan, hanya berkonsentrasi pada pengelolaan earning assets yang berupa pembiayaan dan kurang memperhatikan earning assets dalam bentuk lain yang memiliki prospek yang baik seperti surat-surat berharga, penempatan dana pada bank lain, dan penyertaan modal bank pada lembaga keuangan yang bukan bentuk bank atau perusahaan lain (fee based income). Untuk mengurangi dampak negatif dari adanya risiko pembiayaan (NPF) yang tinggi, fee based income memiliki peranan yang penting. Pendapatan yang tinggi dari pengelolaan asset ini dapat menutup kerugian yang timbul akibat risiko pembiayaan. Hasil penelitian ini diperkuat oleh penelitian Sabir M. et al. (2012); Lemiyana and Litriani (2016); Mahmudah and Harjanti (2016) yang menyatakan bahwa NPF tidak berpengaruh terhadap ROA. Hasil penelitian ini bertolak belakang dengan penelitian yang dilakukan oleh Lestari and Widyawati (2014); 
Christiano et al. (2015); Nugraheni (2015); Sari et al. (2021) yang menyatakan bahwa $N P F$ memiliki pengaruh terhadap $R O A$.

\section{Pengaruh BOPO terhadap ROA}

Hasil hipotesis $\mathrm{H}_{4}$ diterima, artinya terdapat pengaruh yang signifikan antara BOPO terhadap ROA pada BUS. Hal ini mengindikasikan jika BOPO meningkat yang berarti efisiensi menurun, maka ROA yang diperoleh bank akan menurun. Hal ini disebabkan karena tingkat efisiensi bank dalam menjalankan operasinya berpengaruh terhadap pendapatan atau earning yang dihasilkan oleh bank tersebut. Jika kegiatan operasional dilakukan dengan efisien (dalam hal ini nilai rasio BOPO rendah) maka pendapatan yang dihasilkan bank akan meningkat.

Selain itu, besarnya BOPO juga disebabkan karena tingginya biaya dana yang dihimpun dan rendahnya pendapatan dari penanaman dana. Sehingga semakin besar BOPO maka akan semakin kecil ROA yang diperoleh bank. Begitu juga sebaliknya, semakin kecil BOPO maka akan semakin besar ROA dan semakin baik juga kinerja serta posisi keuangan bank. Hasil penelitian ini diperkuat oleh penelitian Lestari and Widyawati (2014); Christiano et al. (2015); Indarwati and Anan (2015); Nugraheni (2015); Hakiim and Rafsanjani (2016); Lemiyana and Litriani (2016) yang menyatakan bahwa BOPO berpengaruh dan signifikan terhadap ROA. Hasil penelitian ini bertolak belakang dengan penelitian yang dilakukan oleh Sabir M. et al. (2012) yang menyatakan bahwa BOPO tidak berpengaruh terhadap $R O A$.

\section{Pengaruh Inflasi terhadap $R O A$}

Hasil hipotesis $\mathrm{H}_{2}$ ditolak, artinya tidak terdapat pengaruh dan tidak signifikan antara inflasi terhadap ROA pada BUS. Hasil ini mengindikasikan bahwa semakin besar nilai inflasi, maka nilai $R O A$ akan meningkat meskipun tidak signifikan. Hal ini dikarenakan sistem Bank Syariah yang tidak menganut sistem bunga, sehingga uang yang dikelola tidak akan terlalu mengalami gejolak apabila mengalami inflasi seperti halnya bank konvensional.

Walaupun demikian bank harus tetap mengantisipasi inflasi karena dapat kemungkinan bahwa biaya bank dapat meningkat lebih cepat dari pada pendapatan bank. Sehingga Bank Umum Syariah harus memiliki kemampuan dalam memprediksi inflasi yang akan datang. Hal ini disebabkan karena diasumsikan bahwa dengan peramalan dan prediksi tingkat inflasi dapat membantu bank dalam membuat kebijakan untuk menentukan tingkat bagi hasil, kuantitas pembiayaan dan kualitas aset. Hasil penelitian ini diperkuat oleh penelitian Wibowo and Syaichu (2013) yang menyatakan bahwa inflasi tidak berpengaruh dan tidak signifikan terhadap ROA. Hasil penelitian ini bertolak belakang dengan penelitian yang dilakukan oleh Sahara (2013); Alim (2014) yang menyatakan bahwa inflasi memiliki pengaruh positif terhadap $R O A$.

\section{Pengaruh $C A R, F D R, N P F$, BOPO dan Inflasi terhadap $R O A$}

Hasil hipotesis $\mathrm{H}_{6}$ diterima, artinya terdapat pengaruh yang signifikan secara simultan antara $C A R, F D R, N P F$, BOPO dan inflasi terhadap $R O A$ pada BUS dengan besar pengaruh $87,27 \%$, sedangkan sisanya $12,73 \%$ dari variabel lain diluar penelitian ini. 


\section{KESIMPULAN}

Berdasarkan hasil penelitian ternyata secara parsial CAR berpengaruh dan signifikan terhadap ROA pada BUS. FDR tidak berpengaruh dan tidak signifikan terhadap ROA pada BUS. NPF tidak berpengaruh dan tidak signifikan terhadap $R O A$ pada BUS. BOPO berpengaruh dan signifikan terhadap ROA pada BUS. Inflasi tidak berpengaruh dan tidak signifikan terhadap $R O A$ pada BUS. Secara simultan $C A R, F D R, N P F$, BOPO dan inflasi berpengaruh signifikan terhadap ROA pada BUS sebesar $87,27 \%$.

Stakeholder dapat menggunakan $C A R$ dan BOPO sebagai penentu tingginya rendahnya $R O A$ pada BUS. Namun $F D R, N P F$ dan inflasi tidak bisa dinafikan, walaupun dalam penelitian ini tidak memiliki pengaruh. Penelitian ini memiliki keterbatasan pada data yang digunakan peneliti dalam pengambilan sampel.

Diharapkan bagi penelitian selanjutnya dapat memperpanjang masa penelitian dan menggunakan variabel lain dalam menentukan ROA pada BUS. Bahkan dapat menambahkan ruang lingkup penelitian, tidak hanya di Indonesia saja, namun dapat memperluas ke negara-negara muslim lainnya.

\section{DAFTAR PUSTAKA}

Alim, Syahirul. 2014. "Analisis Pengaruh Inflasi Dan BI Rate Terhadap Return On Assets (ROA) Bank Syariah Di Indonesia." Jurnal Ekonomi Modernisasi 10 (3): 201-20. https://doi.org/10.21067/jem.v10i3.785.

Christiano, Mario, Parengkuan Tommy, and Ivonne Saerang. 2015. "Analisis Terhadap Rasio-Rasio Keuangan Untuk Mengukur Profitabilitas Pada Bank-Bank Swasta Yang Go Public Di Bursa Efek Indonesia." Jurnal EMBA: Jurnal Riset Ekonomi, Manajemen, Bisnis Dan Akuntansi 2 (4): 817-830. https://ejournal.unsrat.ac.id/index.php/emba/article/view/6490.

Dendawijaya, Lukman. 2005. Manajemen Perbankan. Jakarta: Ghalia Indonesia.

Fahmi, Irham. 2015. Manajemen Perbankan Konvensional Dan Syariah. Jakarta: Mitra Wacana Media.

Fazriani, Anisya Dwi, and Rimi Gusliana Mais. 2019. "Pengaruh Pembiayaan Mudharabah, Musyarakah, Dan Murabahah Terhadap Return On Asset Melalui Non Performing Financing Sebagai Variabel Intervening (Pada Bank Umum Syariah Yang Terdaftar Diotoritas Jasa Keuangan)." Jurnal Akuntansi Dan Manajemen 16 (01): 1-34. https://doi.org/10.36406/jam.v16i01.265.

Hakiim, Ningsukma, and Haqiqi Rafsanjani. 2016. "Pengaruh Internal Capital Adequency Ratio (CAR), Financing To Deposit Ratio (FDR), dan Biaya Operasional Per Pendapatan Operasional (BOPO) dalam Peningkatan Profitabilitas Industri Bank Syariah di Indonesia." Jurnal Aplikasi Manajemen 14 (1): 161-68. https://doi.org/10.18202/jam23026332.14.1.17.

Hutagalung, Muhammad Wandisyah R. 2020. "Determinan Pembiayaan Mudharabah Pada Perbankan Syariah Di Indonesia." Al-Masharif: Jurnal 
Ilmu Ekonomi Dan Keislaman 8 (2): 283-98. http://jurnal.iainpadangsidimpuan.ac.id/index.php/Al-masharif/article/view/3357.

Indarwati, Vivin, and Edy Anan. 2015. "Pengaruh Rasio-Rasio Keuangan Terhadap Kinerja Bank Di Indonesia (Studi Kasus pada Bank Pembangunan Daerah di Indonesia Periode 2008-2012)." EBBANK 5 (2): 35-54.

http://www.ebbank.stiebbank.ac.id/index.php/EBBANK/article/view/5.

Ismail, Ismail. 2010. Manajemen Perbankan. Jakarta: Kencana.

Karim, Adiwarman A. 2006. Ekonomi Makro Islam. Jakarta: PT. Raja Grafindo Persada.

Kuncoro, Mudrajad and Suhardjono Suhardjono. 2012. Manajemen Perbankan Teori Dan Aplikasi. Yogyakarta: BPFE Yogyakarta.

Lemiyana, Lemiyana, and Erdah Litriani. 2016. "Pengaruh NPF, FDR, BOPO

Terhadap Return On Asset (ROA) Pada Bank Umum Syariah." IECONOMICS: A Research Journal on Islamic Economics 2 (1): 31-49. http://jurnal.radenfatah.ac.id/index.php/ieconomics/article/view/1001.

Lestari, Sunariyati Muji, and Nurul Widyawati. 2014. "Faktor-Faktor Yang Mempengaruhi Return On Asset Pada Perusahaan Perbankan Di BEI." Adoc.Pub. 2014. https://adoc.pub/faktor-faktor-yang-mempengaruhireturn-on-asset-pada-perusah.html.

Mahmudah, Nurul, and Ririh Sri Harjanti. 2016. "Analisis Capital Adequacy Ratio, Financing To Deposit Ratio, Non Performing Financing, Dan Dana Pihak Ketiga Terhadap Tingkat Profitabilitas Bank Umum Syariah Periode 2011-2013." Prosiding Seminar Nasional IPTEK Terapan (SENIT) 2016 Pengembangan Sumber Daya Lokal Berbasis IPTEK 1 (1). https://ejournal.poltektegal.ac.id/index.php/prosiding/article/view/370.

Nugraheni, Endang. 2015. Analisis Pengaruh Capital Adequacy Ratio (CAR), Financing To Deposit Ratio (FDR), Beban Operasional-Pendapatan Operasional (BOPO) dan Non Performing Financing (NPF) Terhadap Return On Asset (ROA) Pada PT. Bank Syariah Mandiri. Thesis Program Pasca sarjana UIN-SU. http://repository.uinsu.ac.id/425/.

Pandia, Frianto. 2012. Manajemen Dana Dan Kesehatan Bank. Jakarta: Rineka Cipta.

Pranata, A. A. Alit Wahyu Dwi. 2015. "Pengaruh Capital Adequacy Ratio, Loan To Deposit Ratio dan Ukuran Perusahaan Pada Profitabilitas Bank.” EJurnal Akuntansi $11 \quad$ (1): 235-51. https://ojs.unud.ac.id/index.php/Akuntansi/article/view/10539/.

Rivai, Veithzal, and Arviyan Arifin. 2013. Islamic Banking Sebuah Teori, Konsep Dan Aplikasi. Jakarta: PT. Bumi Aksara.

Sabir M., Muh., Muhammad Ali, and Abd. Hamid Habbe. 2012. "Pengaruh Rasio Kesehatan Bank Terhadap Kinerja Keuangan Bank Umum Syariah Dan Bank Konvensional Di Indonesia." Jurnal Analisis 1 (1): 79-86. https://www.academia.edu/download/49938439/PENGARUH_RASIO_K ESEHATAN_BANK_TERHADAP_K.pdf.

Sahara, Ayu Yanita Yanita. 2013. “Analisis Pengaruh Inflasi, Suku Bunga BI, Dan Produk Domestik Bruto Terhadap Return on Asset (ROA) Bank Syariah Di Indonesia." Jurnal Ilmu Manajemen (JIM) 1 (1): 149-157. https://jurnalmahasiswa.unesa.ac.id/index.php/jim/article/view/1502. 
Sari, Rini Malinda, Fena Ulfa Aulia, Iis Nurul Anami, and Atika Salsabila. 2021. "Pengaruh Pembiayaan Ijarah, Non-Performing Financing Dan Financing To Deposit Ratio Terhadap Return On Assets Pada Unit Usaha Syariah Tahun 2018-2020." JPS (Jurnal Perbankan Syariah) 2 (1): 12-28. https://doi.org/10.46367/jps.v2i1.286.

Taswan. 2010. Manajemen Perbankan: Konsep, Teknik Dan Aplikasi. Yogyakarta: UPP STIM YKPN Yogyakarta.

Wibowo, Edhi Satriyo, and Muhammad Syaichu. 2013. "Analisis Pengaruh Suku Bunga, Inflasi, CAR, BOPO, NPF Terhadap Profitabilitas Bank Syariah.” Diponegoro Journal of Management 2 (2): 10-19. https://ejournal3.undip.ac.id/index.php/djom/article/view/2651. 